\title{
Influence of Coal Ash on Dense Bituminous Macadam
}

\author{
Mr. Ganesh S. Gujrathi, PG Student, Dr. Rajendra Gode Institute of Technology \& Research,
} Amravati, India, ganesh.gujrathi11@gmail.com

Mr. Sarang P. Mahajan, Assistant Professor, Sipna College of Engineering and Technology, Amravati, India, sarangmahajan@ rediffmail.com

Mr. Sagar K. Sonawane, Assistant Professor, RMD Sinhgad School of Engineering, Pune, India, sagar17793@gmail.com

Abstract- In the present study, dense graded bituminous mix specimens are prepared using natural aggregate as coarse aggregates, bottom ash as fine aggregates and coal ash as filler. Proportion of aggregate for dense graded bituminous macadam (DBM) grading has been considered as per MORTH (2013) having nominal maximum aggregates size (NMAS) $26.5 \mathrm{~mm}$. The bitumen used is VG20. Firstly, bottom ash and fly ash was used as fine replacement in DBM mix. In this, the total coal ash content is taken as $35 \%$ by weight of the total mix, from which the percentage of fly ash as mineral filler is fixed, i.e. $5 \%$ of weight of the mix. The bottom ash content is varied according to the DBM gradation specified in MORTH (2013). Detailed study with Marshall test results were used to determine the Marshall characteristics, optimum binder content and also optimum use of coal ash. The maximum stability value of $11.826 \mathrm{kN}$ was achieved when $14 \%$ of coal ash by weight of the mix was mixed for preparing DBM samples. It is finally observed that results are not only satisfactory, but also much improved engineering properties with coal ash as fine aggregate and filler. Utilization of non-conventional aggregate like coal ash may help to find a new way of bituminous pavement construction.

Keywords — Bitumen, Bituminous Pavement, Coal Ash, Dense Bituminous Macadam, Marshall Stability, Optimum Binder Content.

\section{INTRODUCTION}

Coal-based thermal power plants have been a key source of power generation in India. The prime waste product of a coal thermal power plant are fly ash and bottom ash. Heavy dumping of these waste products causes fatal environment pollution to air, water and land, besides impairing human health. This research work is done to deliver the optimum use of ash, namely bottom ash as fine aggregate and fly ash as mineral filler used to improvise the engineering properties of bituminous paving mixes. For national interest these waste products, which are available easily and abundantly can be used economically for bituminous paving purpose, which ultimately helps in saving the natural aggregate resources of the nation. The coal ash dumping which is a serious concern to everyone in respect of its disposal and environmental pollution, can find one way for its reuse in an economical way by substituting natural resources of sand and stone dust.

\section{Materials USED}

A bituminous mix is made from aggregate, graded from maximum fraction to smaller fraction (usually less than 25 mm IS sieve to the mineral filler, smaller than $0.075 \mathrm{~mm}$ IS sieve), which are blended with bitumen binder to form a consistent mixture. This mixture is then laid and compacted to achieve an elastic body which is seamlessly impervious and hard. The study of mix design is to attain the suitable proportion of aggregate, bitumen and other additives if added.

\section{A. Coarse Aggregates}

Coarse aggregates comprised of stone chips were procured from a nearby crusher and were stored by sieving in to different sizes. For this study, stone chips comprising coarse aggregate fractions and upper size fractions of fine aggregates ranged from $26.5 \mathrm{~mm}$ to $0.3 \mathrm{~mm}$ were used as shown in Figure 3. For lower fractions of fine aggregates and mineral filler, bottom ash and fly ash were respectively used to the extent of $9 \%$ and $5 \%$ by weight of total mix. Bottom ash and fly ash was procured from the nearby Eklahare, Nashik thermal power plant (shown in Figure 2 and 1). The physical properties of coarse aggregates and fine aggregates which are primarily required for paving are given in Table 1 


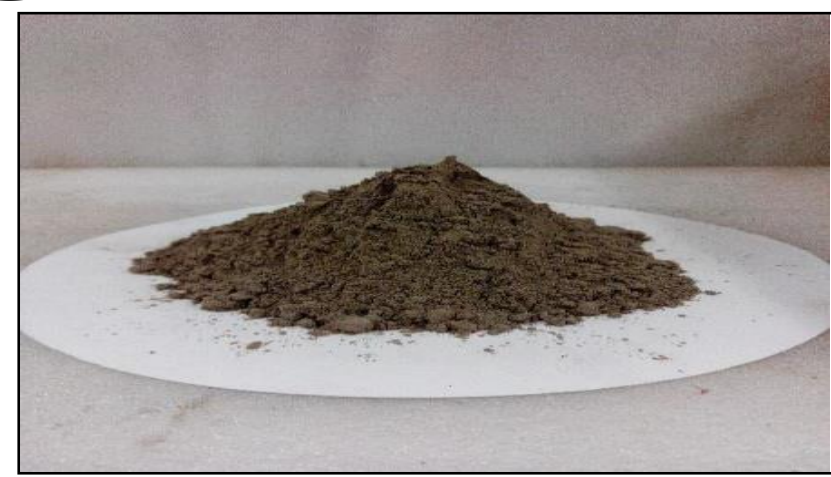

Fig.1 Fly ash

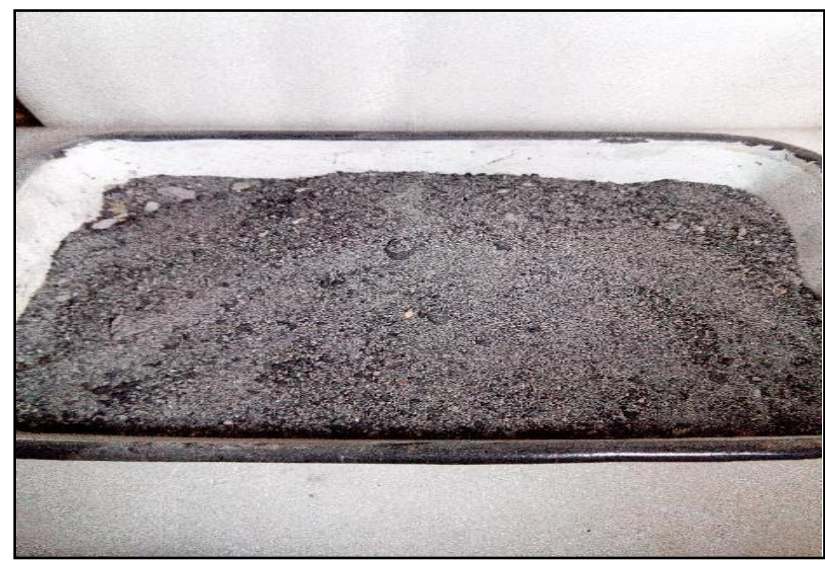

Fig.2 Bottom ash

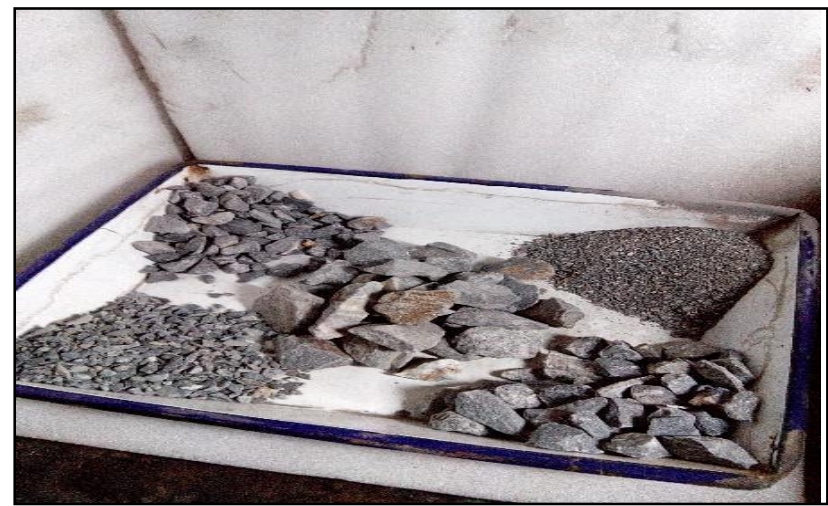

Fig.3 Stone chips

Table 1 Physical properties of coarse and fine aggregates

\begin{tabular}{|l|c|c|c|}
\hline \multicolumn{1}{|c|}{ Property } & $\begin{array}{c}\text { Code } \\
\text { specification }\end{array}$ & $\begin{array}{c}\text { Natural } \\
\text { Aggregate }\end{array}$ & $\begin{array}{c}\text { Bottom } \\
\text { ash and } \\
\text { fly ash }\end{array}$ \\
\hline $\begin{array}{l}\text { Aggregate crushing } \\
\text { value, \% }\end{array}$ & IS:2386 part-IV & 13.7 & - \\
\hline $\begin{array}{l}\text { Aggregate impact } \\
\text { value, \% }\end{array}$ & IS:2386 part-IV & 14.25 & - \\
\hline $\begin{array}{l}\text { Los Angles Abrasion } \\
\text { test, \% }\end{array}$ & IS:2386 part-IV & 18.92 & - \\
\hline Flakiness index, \% & IS:2386 part-I & 11.89 & - \\
\hline Elongation index, \% & IS:2386 part-I & 12.59 & - \\
\hline Water absorption, \% & IS:2386 part-III & 0.13 & 10.54 \\
\hline Specific gravity & IS:2386 part-III & 2.7 & 2 \\
\hline
\end{tabular}

\section{B. Bitumen}

The paving bitumen grade VG20 (VG-viscosity grade) was used in this experimental study. Especially the Marshall stability in respect of mixes made up of bottom ash, fly ash with VG20 bitumen as binder. The physical characteristics of VG20 bitumen tested as per IS standards are given in Table 2.

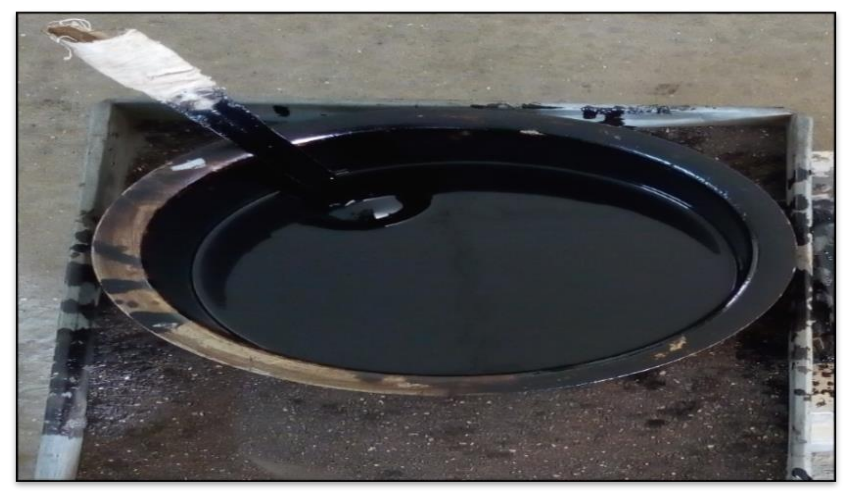

Fig.4 Experimental Bitumen

Table 2 Physical properties of binder

\begin{tabular}{|l|c|c|}
\hline \multicolumn{1}{|c|}{ Physical Properties } & IS Code & Test Result \\
\hline Penetration at $25^{\circ} \mathrm{C}$ & IS:1203-1978 & 72.7 \\
\hline Softening Point, ${ }^{\circ} \mathrm{C}$ & IS:1203-1978 & 48.5 \\
\hline Flash Point, ${ }^{\circ} \mathrm{C}$ & IS:1209-1978 & 226 \\
\hline Specific gravity, at $27{ }^{\circ} \mathrm{C}$ & IS:1202-1978 & 1.01 \\
\hline $\begin{array}{l}\text { Kinematic Viscosity, } 135^{\circ} \mathrm{C}, \\
\text { CST }\end{array}$ & IS 1206 (Part 3) & 305 \\
\hline
\end{tabular}

\section{EXPERimental Methodology}

The DBM mixtures were prepared in accordance with the Marshall procedure specified in ASTM D6927-2015. All ingredients of mixture, such as coarse aggregates, fine aggregates, filler and VG-20 bitumen were mixed in a specified procedure.

The aggregates and bitumen were heated separately to the mixing temperature of $155^{\circ} \mathrm{C}$ to $160^{\circ} \mathrm{C}$. The temperature of the aggregates was maintained $10^{\circ} \mathrm{C}$ higher than that of the binder. Required quantities of bitumen VG20 were added to the pre-heated aggregates and thoroughly mixed. Proper mixing was done manually till the colour and consistency of the mixture appeared to be uniform. The mixing time and temperature was maintained within 2-5 minutes and $150^{\circ} \mathrm{C}-160^{\circ} \mathrm{C}$ respectively. The mixture was then poured in to a pre-heated Marshall mould and compacted using Humboldt Automatic Marshall Compact with 75 compaction blows on each side. The specimens were kept 24 hours for cooling to a temperature of $25 \pm 1^{\circ} \mathrm{C}$. In this experiment, the resistance to deformation of a Marshall cylindrical specimen of DBM mixture is measured. The specimen is loaded diametrically at a deformation rate of $50 \mathrm{~mm} / \mathrm{min}$. Here are two major features of the Marshall method of mix design are given below.

\section{Stability and flow values}

2. Voids analysis.

The Marshall stability for bituminous mix is defined as the maximum resistance carried by specimen at a standard temperature of $60^{\circ} \mathrm{C}$. The flow value is recorded when the 
specimen deformed under maximum. The Marshall voids analysis were done before the Marshall stability test. In this voids analysis bulk specific gravity (Gmb), air voids (VA), voids in mineral aggregate (VMA), voids filled with bitumen (VFB).

\section{Discussion OF Results}

This section deals with the comparison of coal ash in DBM mixes with conventional DBM Mix.

\section{A. Marshall Stability}

It is seen from the figure 5 that using of coal ash in DBM mix is not satisfactory with respect to stability value, when compared with conventional mix. The maximum stability value of $11.826 \mathrm{kN}$ was achieved when $14 \%$ of coal ash by weight of the mix was mixed for preparing DBM samples.

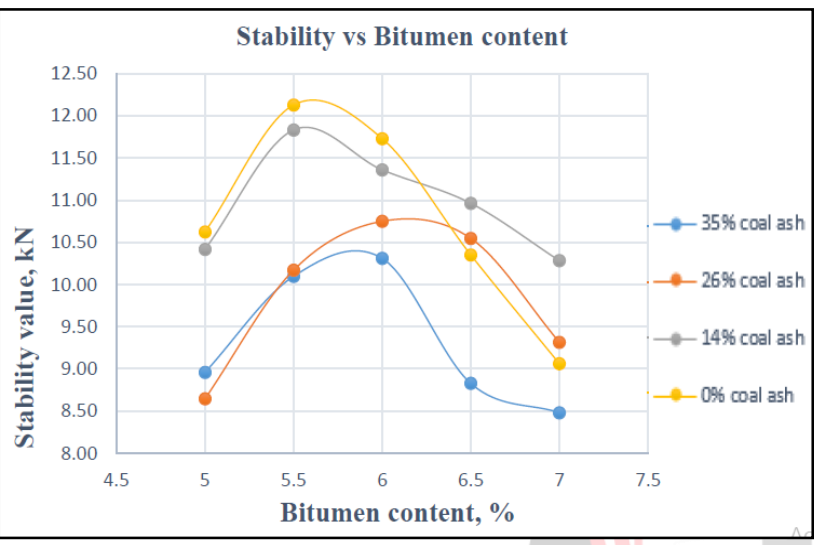

Fig.5 Variation of stability value with bitumen content at different coal ash content

\section{B. Marshall Flow}

It was seen from the flow value vs bitumen content graph shown in figure 6 that with increase in bitumen content and coal ash content the flow value increase. But with $14 \%$ coal ash content by weight of mix the flow value decrease as compare to the conventional mix.

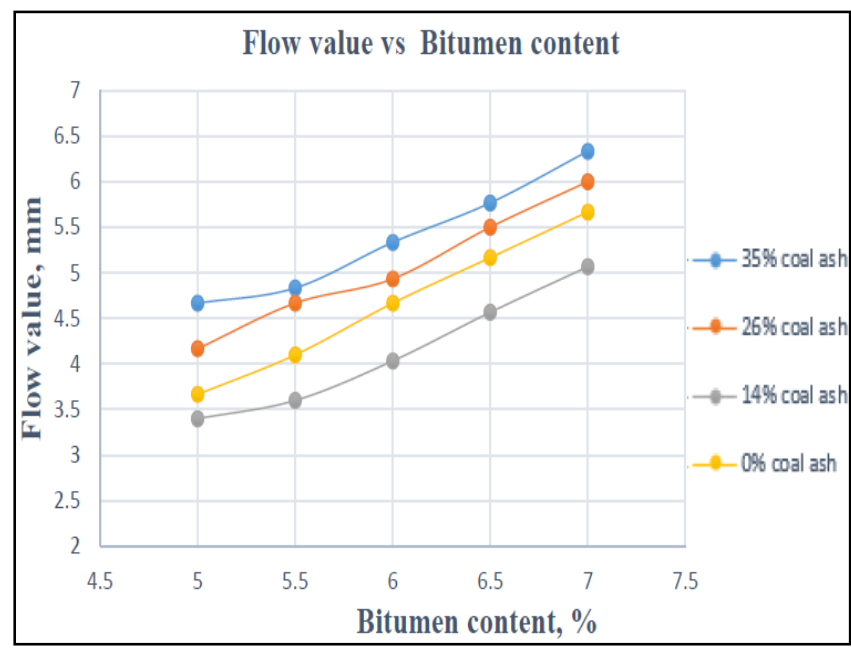

Fig.6 Variation of flow value with bitumen content at different coal ash content

\section{Air Void}

It is observed from the graph shown in figure 7 that with increase in coal ash the air void increases. By taking $14 \%$ coal ash by weight of the mix, the air void is fairly near to the conventional mix, which means coal ash can be used with some modification to achieve optimum properties than conventional mix.

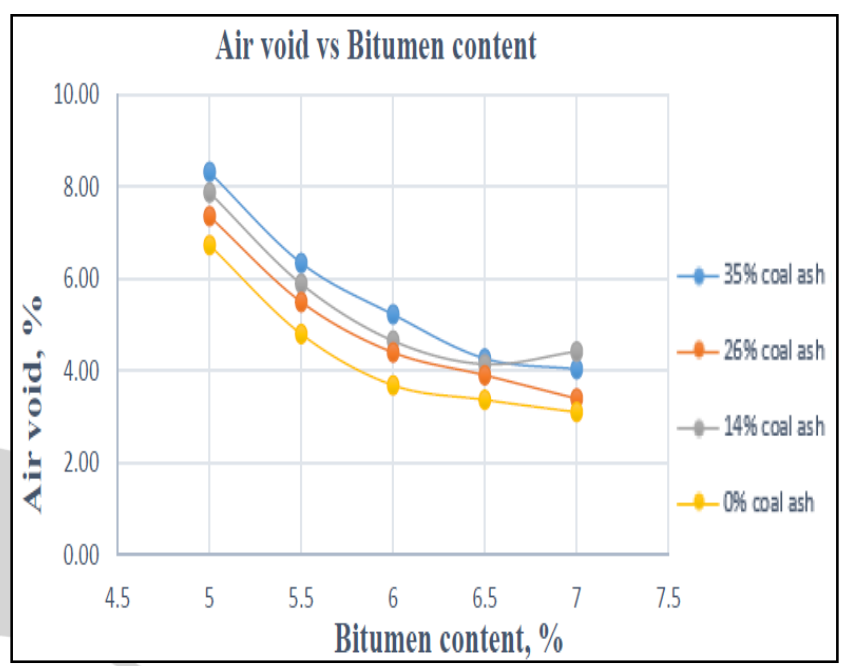

Fig.7 Variation of air void value with bitumen content at different coal ash content

\section{Unit Weight}

From the unit weight and bitumen content graph shown in figure 8 , it is observed that with increase in coal ash content the unit weight of DBM samples decreases. Coal ash been a lighter material cause the decrease of unit weight.

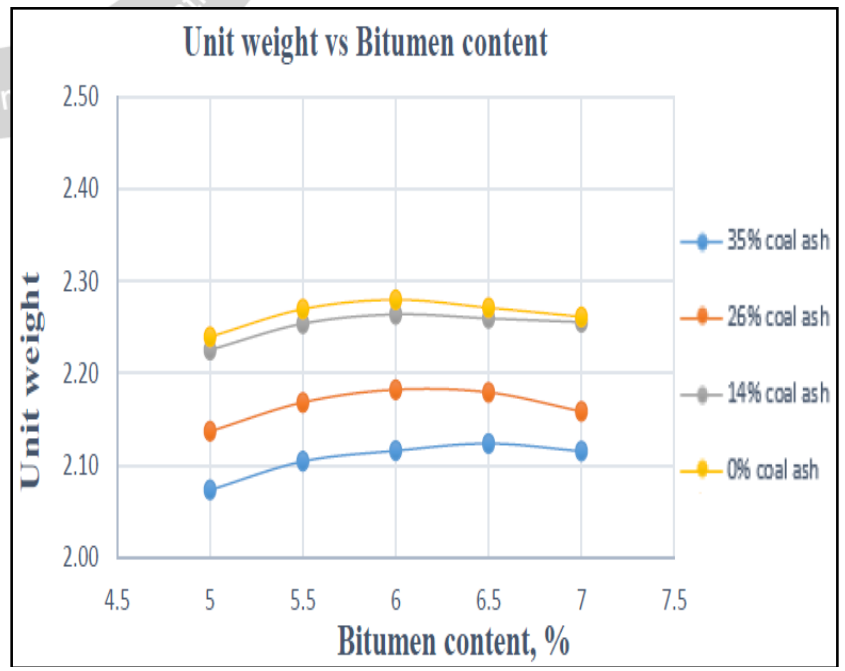

Fig.8 Variation of unit weight value with bitumen content at different coal ash content

E. VMA

From the observation of VMA vs bitumen content graph in figure 9 , it is clear that with increase in bitumen content voids in mineral aggregate decrease rapidly first and then increases steadily. 


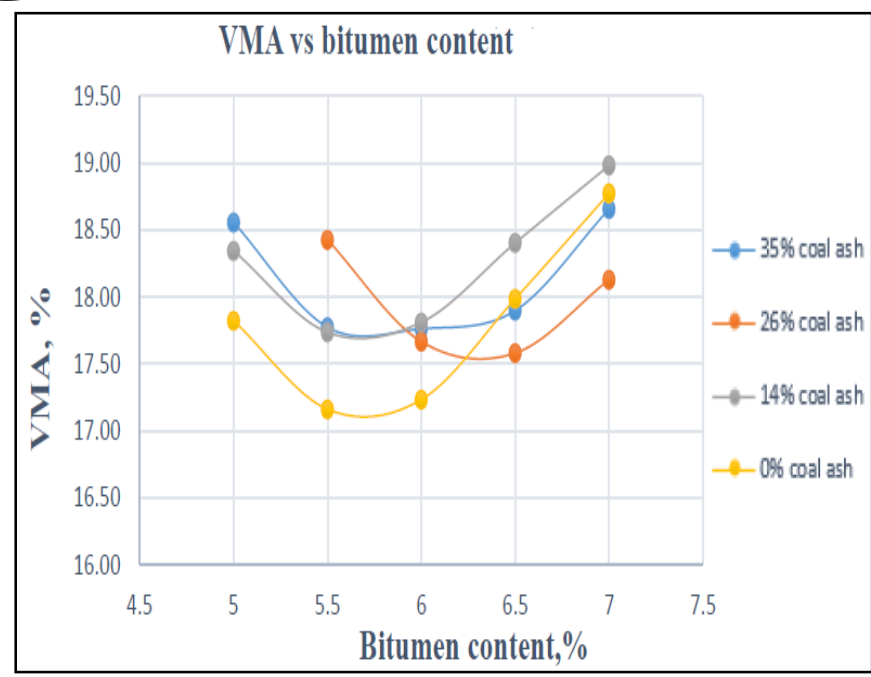

Fig.9 Variation of VMA value with bitumen content at different coal ash content

\section{F. $V F B$}

It is observe from the VFB and bitumen content graph shown in figure 10 that VFB increase rapidly with increase in bitumen and coal ash content.

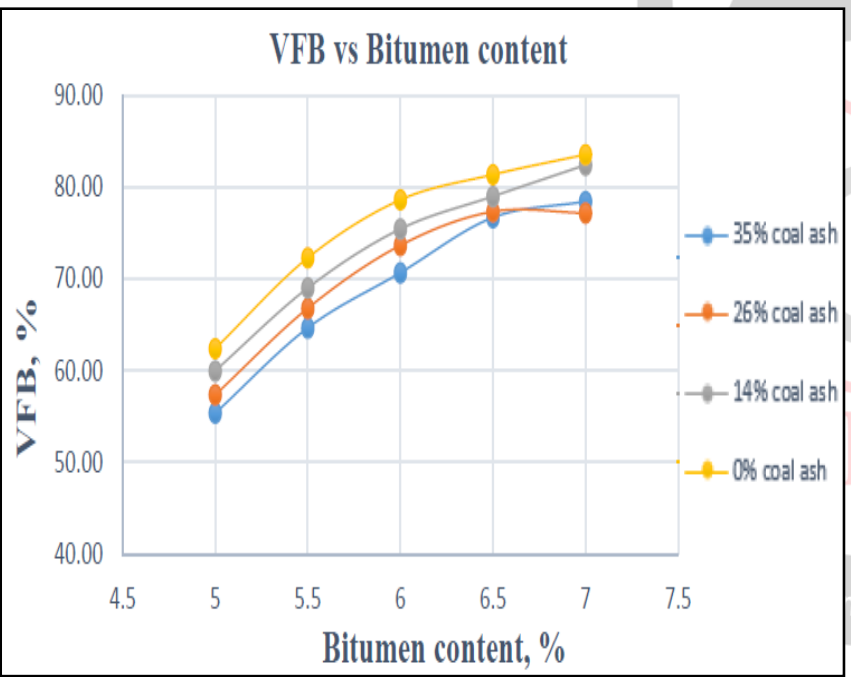

Fig.10 Variation of VFB value with bitumen content at different coal ash content

\section{Conclusion}

From the results of the Marshall tests it was observed that the DBM mixes prepared with bottom ash and fly ash used respectively in 300-75 micron sizes and passing 75 micron resulted best mixes satisfying the Marshall criteria when bitumen content were $5.600 \%$. It is also observed that Marshall stability and flow values are quite acceptable when the coal ash content is within $15 \%$. So we can replace the coal ash with conventional fillers in the DBM mixes.

\section{REFERENCES}

[1] AASHTO T 283, "Standard method of test for resistance of compacted asphalt mixtures to moisture- induced damage", American association of state highway and transportation officials.

[2] Ali, N., Chan, J. S., Simms, S., Bushman, R., \& Bergan, A. T.; "Mechanistic evaluation of fly ash asphalt concrete mixtures". Journal of Materials in Civil Engineering, (1996), 8(1), 19-25.

[3] Al-Suhaibani, A. S., \& Tons, E. T.; "Properties of fly ash-extended-asphalt concrete mixes." Transportation Research, (1991).

[4] ASTM D 1559, "Test method for resistance of plastic flow of bituminous mixtures using Marshall Apparatus", American society for testing and materials.

[5] Chakroborty, P., \& Das, A. "Principles of Transportation Engineering", Prentice Hall of India, New Delhi, (2010), pp 294-299.

[6] Colonna, P.; Berloco, N., Ranieri, V., \& Shuler, S. T. (2012), "Application of bottom ash for pavement binder course." Procedia-Social and Behavioral Sciences 53 (2012): 961-971.

[7] Gunalaan, V.; "Performance on Coal Bottom Ash in Hot Mix Asphalt" International Journal of Research in Engineering and Technology, (Aug 2013) eISSN: 2319-1163 | pISSN: 2321-7308.

[8] Hadiwardoyo, S. P.; "Evaluation of the addition of short coconut fibers on the characteristics of asphalt mixtures." Civil and Environmental Research 3.4 (2013): 63-73.

[9] Khanna, S. K., \& Justo, C. E. G. (1991); "Highway engineering". Nem Chand \& Bros, (1991).

[10] Ksaibati, K., \& Sayiri, S. R. K.; "Utilization of Wyoming bottom ash in asphalt mixes". No. MPC Report No. 06-179. Mountain Plains Consortium, (2006).

[11] Ksaibati, K., \& Stephen, J.; "Utilization of bottom ash in asphalt mixes". No. MCP Report No. 99-104A. Department of Civil and Architectural Engineering, University of Wyoming, (1999). 